\title{
THE IMPACT OF ECONOMIC, DEMOGRAPHIC, AND INFRASTRUCTURAL FACTORS ON INCOME INEQUALITY AND POVERTY IN RUSSIA. Rogneda Groznykh ${ }^{1}$, Elena Ignatieva ${ }^{2}$, Oleg Mariev ${ }^{3,4}$, Alla Serkova ${ }^{4,5}$
}

\begin{abstract}
The prime objective of the research is to examine the factors influencing both the alteration in the income distribution and the relative change in the incidence of poverty in the regions of Russia. The list of the identified factors/determinants includes economic, demographic, and infrastructural factors. An econometric model, indicating the relationship between the explanatory variables with both the income inequality index and the relative poverty proportions in Russian regions has been provided in this article. The determinants that cause variations in the income inequality and poverty of a country such as social mobility, average life expectancy of urban women, life expectancy of rural men, the number of university graduates, etc. have also been specified in this study. The analysis was executed based on a dataset of 72 Russian regions for the period between 2012-2017.
\end{abstract}

JEL Classification Numbers: I32, I38, DOI: https://doi.org/10.12955/peb.v1.21

Keywords: Poverty, Distribution of the Incomes, Policy Measurements

\section{Introduction}

The issue of income inequality and its functional and ultimate distribution has always been one of the traditional fundamental problems of economic theory. Income inequality emerges as a consequence of commodity production and the division of society into classes. Subsequently, this inequality has deepened with the development of social relations. In the first place, a problem of proper and equitable distribution of income exists in Russia; secondly, the most significant of socio-economic problems in Russia is that of poverty, and in today's world, it is given great importance. For example, many economists have dedicated years of hard work and study to the analysis of the problem of poverty in Russia and the possible ways to combat it. Still this concern remain relevant till date due to the fact that there are many interpretations of the solutions to the problems related to the generation, allocation and redistribution of income, and determining the actual cause behind the increase in the number of poor people. Therefore, researchers have not yet come to a consensus on which solution is to be suggested, because virtually every scientific direction in economic theory advances and, somehow, solves the problem of income inequality, resulting in innumerable solutions. The government of the Russian Federation concentrates on the issue of inequality in income distribution and that of poverty, but they use analogous techniques to solve them. The aim of this research is to identify factors that cause income inequality and the relative number of poor people. The authors examine the possible factors that influence inequality and poverty, then gather and assemble the data into a database, present models of the implications of regional indicators on inequality and poverty, and at the end conduct a comparative analysis of the impact of these factors and make suitable conclusions based on them.

\section{Literature Review}

The problem of income inequality has been widely debated by scientists in the world. In one of the works of Cristiano P. and Gaetano M. (2008) "Income Inequality Within European regions: Determinants and Effects on Growth", the concept of income inequality is emphasized upon (Cristiano and Gaetano, 2008). The authors developed an econometric model for their research, for which the data for the period between 2012-2017 on 72 regions of Russia (excluding Moscow, Saint Petersburg and Crimea), was used. Much of the information for the database was also sourced from the websites of the Federal State Statistics Service of Russian Federation.

Another article by Chen et al. (2014) explored the relationship between income inequality, poverty, and income mobility of urban residents. Halvarsson et al. (2017) in their article investigated

\footnotetext{
${ }^{1}$ Graduate School of Economics and Management, Ural Federal University, Yekaterinburg, Russian Federation, ronav999@gmail.com

2 The Ural Branch of Russian Academy of Sciences, Yekaterinburg, Russian Federation, elen_i99@mail.ru

${ }^{3}$ Graduate School of Economics and Management, Ural Federal University, and Institute of Economics, The

Ural Branch of the Russian Academy of Sciences, Yekaterinburg, Russian Federation, o.s.mariev@urfu.ru

${ }^{4}$ Institute of Economics, The Ural Branch of the Russian Academy of Sciences, Yekaterinburg, Russian

Federation

${ }^{5}$ Graduate School of Economics and Management, Ural Federal University, Yekaterinburg, Russian Federation, muccio@bk.ru
} 
entrepreneurship, as a source of increased capital mobility for some, on one hand, and as a potential cause of poverty for the rest, on the other. Oancea et al. (2017) presented a study as a part of their research on the allocation of personal income and the inequality in this allocation in Romania, processing individual tax income data using non-parametric and parametric methods. Jagielski et al. (2015) also did a similar comparison on the distribution of income in the European Union and the United States in their work.

The works on income inequality by other authors discuss differences in income between individuals or families or even between different population groups, regions or countries (Perron, 1998; Wood, 1995; Townsend, 1993; Ahluwalia, 1976). They assess income inequality between different population groups in the regions of Russia as one of the dependent variables. Income inequality can be viewed on the positive side, but the issue with Russian economy is that a majority of the population is divided on the basis of income into very rich and very poor or there exists a gap between the haves and have- nots, with a small layer of the middle class.

The dependent variable in this research is poverty. Poverty is deemed to be an attribute of the economic situation of an individual or social group, in which they cannot meet a certain set of minimum requirements for essentials of life, preservation of working capacity, procreation, etc. (Bigsten and Levin, 2001; Blau and Kahn, 1996; Castelló-Climate, 2010; Emwanu et al., 1995)

As per the standards set by the World Bank, Russia is classified as a moderately-developed country in terms of GDP, and as a developing country in terms of poverty (Ferreira, Gignoux, 2011; Grootaert, 1994). The foremost solution in order to overcome absolute poverty is to ensure productive employment, increase labor efficiency, and to create conditions favorable for the population that is engaged in providing labor, so that they can earn enough to support themselves and their families. In the aforementioned case, the amount of wages received act as the only guarantee against poverty. The role of the government is to create market conditions to strengthen the marketability of the national economy by way of ensuring the competitiveness of Russian enterprises, implying the necessary industrial policies, necessary adoption of education and training systems, the execution of the required initiatives for the protection of domestic producers, etc. (Guvenen et al., 2014; Hertz et al, 2007)

\section{Data and Methodology}

In the process of the investigation, we viewed inequality and poverty were interlinked in such a way that reducing the level of poverty certainly lead to reduction of income inequality. In addition to this, one of our major objectives was to reflect if the same variables affected these indicators in a similar fashion, and provided policy recommendations to work out the identified challenges. It was in accordance with the literature review that the basic model for income inequality was developed. It is represented by equation (1):

$$
\text { Ineq }_{i}=\alpha(\text { Econ })_{i}+\beta(\text { Demo })_{i}+\gamma(\text { Infr })_{i}+\mu(\text { Country })_{i}+\varepsilon_{i}
$$

where the dependent variable is the 'Gini index'. Independent variables were further segregated into several groups: i) economic, ii) demographic, iii) infrastructural, and iv) country-based. For econometric analysis, ordinary least squares (OLS) estimation method was applied. Based on the results of the econometric analysis, the regression was pivotal in its completeness, which was then confirmed by the Wald Test. Our main hypothesis suggested that every coefficient was important in our models. The models are depicted as follows:

$$
\begin{gathered}
\text { Gini }_{i}=\alpha\left(\text { Econ }_{i}+\beta\left(\text { Demo }_{i}+\gamma(\text { Infr })_{i}+\varepsilon_{i},(2)\right.\right. \\
\text { Poverty }_{i}=\alpha(\text { Econ })_{i}+\beta(\text { Demo })_{i}+\gamma(\text { Infr })_{i}+\varepsilon_{i},(3),
\end{gathered}
$$

where Econ, Demo and Infr stand for the variables from the corresponding groups (economic, demographic, infrastructural). The division of indicators into groups is portrayed only to simplify the concept of the models. The groups of factors for the study are represented in Table 1.

\section{Results and Discussion}

In table 2, the results of regression estimation are exhibited. We reject the hypothesis that all variables are significant in both the models, as they are not.

It therefore becomes erroneous to assume that the same technique can be used to combat both poverty and income inequality, which is why each variable was independently used in both the models. Furthermore, we excluded the percentage of university graduates from the population of the region as 
well as the number of doctors per 10,000 people from further study, because they were apparently useless for the models.

\begin{tabular}{|l|l|l|l|}
\hline \multicolumn{2}{|l|}{ Table 1: Groups of factors by indicators } \\
\hline No. & Types of Factors & Indicators \\
\hline 1 & Economic & $\begin{array}{l}\text { a) General regional product (GRP) per capita; b) The share of } \\
\text { investments in fixed assets; c) The unemployment rate }\end{array}$ \\
\hline 2 & Demographic & $\begin{array}{l}\text { a) The population density; b) The life expectancy of urban men; c) The } \\
\text { life expectancy of urban women; d) The employment rate; e) The share } \\
\text { of the urban population; f) The life expectancy of rural men; g) The life } \\
\text { expectancy of rural women }\end{array}$ \\
\hline 3 & Infrastructural & $\begin{array}{l}\text { a) The number of University graduates; b) The share of University } \\
\text { graduates in the population of the region; c) Number of doctors per } \\
\text { 10,000 population }\end{array}$ \\
\hline
\end{tabular}

\begin{tabular}{|c|c|c|c|c|}
\hline Explaining Variables & $\begin{array}{l}\text { Significance } \\
\text { Level for Gini }\end{array}$ & $\begin{array}{l}\text { Coefficient for } \\
\text { Gini }\end{array}$ & $\begin{array}{l}\text { Significance } \\
\text { Level for } \\
\text { Poverty }\end{array}$ & $\begin{array}{l}\text { Coefficient for } \\
\text { Poverty }\end{array}$ \\
\hline The Population Density & at $10 \%$ & 0.000101460 & not significant & - \\
\hline $\begin{array}{l}\text { The Share of University } \\
\text { Graduates in the } \\
\text { Population of the Region }\end{array}$ & at $1 \%$ & 0.246066 & not significant & - \\
\hline GRP Per Capita & at $1 \%$ & $5.16718^{\wedge} \mathrm{e}-08$ & at $5 \%$ & $-1.03693^{\wedge} \mathrm{e}-07$ \\
\hline $\begin{array}{l}\text { The Share of the Urban } \\
\text { Population }\end{array}$ & not significant & - & at $1 \%$ & -0.00753367 \\
\hline $\begin{array}{l}\text { The Life Expectancy of } \\
\text { Urban Men }\end{array}$ & at $10 \%$ & -0.00167878 & not significant & - \\
\hline $\begin{array}{l}\text { The Life Expectancy of } \\
\text { Rural Men }\end{array}$ & not significant & - & at $5 \%$ & -0.0196297 \\
\hline $\begin{array}{l}\text { The Life Expectancy of } \\
\text { Urban Women }\end{array}$ & at $10 \%$ & -0.00271498 & at $1 \%$ & -0.0284671 \\
\hline $\begin{array}{l}\text { The Life Expectancy of } \\
\text { Rural Women }\end{array}$ & not significant & - & at $1 \%$ & -0.5369 \\
\hline $\begin{array}{l}\text { The Share of Investments } \\
\text { in Fixed Assets }\end{array}$ & at $1 \%$ & 0.000622634 & at $10 \%$ & 0.00201633 \\
\hline The Unemployment Rate & at $1 \%$ & -0.00301558 & at $1 \%$ & 0.0769148 \\
\hline The Employment Rate & at $1 \%$ & -0.00121089 & at $1 \%$ & 0.0305690 \\
\hline
\end{tabular}

Source: Authors

The explained variable in the first model is the Gini index. The population density for this model is notable at a $10 \%$ level. The coefficient is positive. All other things being constant, if the population density increases by 1000 people, the inequality index will increase by $0.1 \%$ on an average. Presumably, population density corresponds to the presence of families and large households that can relatively accumulate income more easily than individuals, which expands income-earning. The number of university graduates for this model is significant at a $1 \%$ level and has a positive impact on the Gini Index. Other things being constant, when the number of graduates decreases, inequality decreases by $0.25 \%$ on an average. Since university graduates are more likely to get a reputed, high-paying job, this may explain the rise in inequality. GRP per capita for this model is notable at a $1 \%$ level and positively affects the explained variable. When the GRP per capita unit decreases, the level of inequality also decreases, implying that by reducing the volume of gross production for rich households in each region, they will be accorded lesser income, which will subsequently reduce their share and as a consequence, reduce inequality. In simpler terms, elevated GRP per capita decreases inequality "from the top", by reducing the share of the wealthiest households. It can also be assumed that an increase in GRP per capita would increase the distribution of income in the region, which in its turn will increase inequality. The life expectancy of men in urban populations is prominent at $10 \%$ and this has a negative impact on the inequality index. If the life expectancy of urban men increases by one year, the income inequality 
decreases by $0.01 \%$. This can be further elaborated by the fact that men are more hardworking in contrast to women, according to statistics. They usually work in more dangerous and well-paid jobs (for example, in mines or on shift work in the far North). The life expectancy of urban women, on the other hand, is notable at $10 \%$ and it also has a negative impact on the dependent variable. When the life expectancy of women in cities increases, the level of inequality decreases by $0.02 \%$ on an average. This may occur when women in cities work equivalent to men and earn a comparable wages. The share of investments in fixed assets is significant at the level of $1 \%$ and it positively affects the Gini Index. When companies invest more, the level of economic inequality increases by $0.0006 \%$ on an average. This is quite logical and makes perfect sense as investments increase the potential revenue from the company's economic activities. Owners of companies and the senior management will receive high dividends even when the salary for lower-level employees remains the same.

The unemployment rate is significant at $1 \%$ and affects income inequality negatively. When the unemployment rate falls, the level of income inequality rises by $0.003 \%$ on an average. For example, unemployed individuals have diverse mental abilities, pliancy of mind, and other personal indicators, therefore, they can apply for employment at various positions ranging from a specialist to a chief manager. It is imperative that the income on these positions would also vary, which could add on to income inequality. The employment rate, thus has a prominent and negative impact on income inequality. When the employment rate increases, the level of economic inequality of the population decreases by $0.001 \%$ on an average. It is important to note that this variable includes the number of selfemployed people as well. It is can further be elaborated that income inequality decreases when the employed population increases. In other words, this indicator restricts inequality "from below" by reducing poverty-struck unemployed populations, which got jobs when employment increased.

The next step was to run a regression in which the level of poverty becomes the explained variable and the GRP per capita has a significant coefficient. With an increase in GRP per capita by one unit, the level of poverty in the region decreases. This can be explained as a situation when an increase in the gross product involving the relative immutability of the population, the distribution of goods per household increases, as a result of which households produce more goods and consequently generate more income. The share of urban population is prominent at $1 \%$ and this has a negative impact on poverty, suggesting that with an increase in the share of the urban population per unit, the level of inequality will decrease by $0.008 \%$ on an average. Such a situation occurs when cities have numerous options to earn money and to improve the economic condition of households. The life expectancy of rural men is prominent at a 5\% level and negatively affects poverty. If the life expectancy of rural men increases by 1 year, the relative poverty rate decreases by $0.019 \%$ on an average. This can be explained by the understanding that men being the main earners of families, get "more time" to get out of poverty and increase their level of income and lift the household as and when their life expectancy increases. The life expectancy of urban women is significant at the level of $1 \%$. If the life expectancy of urban women increases by 1 year, it will reduce the relative poverty level by $0.028 \%$. Speaking of income inequality, this can be explained by the fact that in cities, women can work on equal basis with men and also receive similar wages. The life expectancy of rural women negatively influences poverty. It means that if the life expectancy of rural women increases by 1 year, the poverty rate will decrease by $0.53 \%$ on an average. An increase in the life expectancy of women will allow them to work longer and, as a result, receive higher wages, which will eventually lead poor household into becoming wealthier.

This effect can also be associated with the previous variable. When elderly people with low incomes shift to rural areas, their life expectancy increases, but poverty may decrease in the region, since they can already earn extra money by way of their farms in the area. The unemployment rate is notable at $1 \%$ and has a positive impact on poverty. If the unemployment rate decreases per unit, the poverty rate also decreases by $0.077 \%$ on an average. This happens due to the fact that when the unemployment rate decreases (in case of an increase in the number of jobs), household income increases. The employment rate is prominent at $1 \%$ and has a positive impact. When the employment rate increases, the poverty rate also increases by 0.031 on an average. This may occur on account of the presence of higher employment levels in regions where there are fewer freelancers or self-employed people (which the indicator rules out) and more poverty-ridden populations, while in regions with lower official employment, there are more unrecorded self-employed people than the actual poor.

\section{Conclusion}


We utilized explained variables to study the indicators that influence both income inequality and the relative number of poor people in Russia's regions, because they are principally significant for the country's development, in terms of both the economic and the socio-demographic spectrum. In this article, we created a model that demonstrated and examined the relationship of various factors with the income inequality index as well as with the relative number of poor in Russia's regions. In order to build the models, we decided to use the same explanatory variables to investigate whether the same indicators affected the problems of income inequality and the relative level of poverty. However, it should be emphasized that in spite of the ongoing research being conducted in many Russian research centers, we are unfamiliar with the manner in which the Russian economy and social life work. This problem stems from the lack of data for deep empirical research. As there is a state policy to address the issues of inequality and poverty, we believe that the efforts made are insufficient, and the initiatives taken to tackle each individual problem are usually inadequate. The focus is mainly on the "symptoms" rather than the "cause". We can recommend the following measures to overcome poverty in Russia:

1) Introducing a living wage separately for different categories of the population (for urban, rural, and cities inhabited by millions). This would in turn enable us to devise more specific programs which would further support particular social categories of the population (Martin, 2014).

2) Tightening rules and regulations regarding criminal liability for paying wages that do not meet the established minimum subsistence.

3) Maintaining a fairly strict price-fixing policy by the government, because it is incredibly necessary to fix the prices of all the essential everyday items and products included in the food basket of a resident of the country and that are needed for sustaining life.

4) Raising pensions to the minimum subsistence level (while benefits are not accounted for).

5) Raising scholarship and bursary payments, at least to the cost of an individual's food basket, so that students are able to survive without the fear of rendering themselves helpless and unaided by parents or relatives.

\section{Acknowledgements}

The article was prepared with the support of the Institute of Economics of the Ural Branch of the Russian Academy of Sciences in accordance with the state task of the Ministry of science and higher education of the Russian Federation (GR No. 0404-2019-0015).

\section{References}

Ahluwalia, M. (1976). Inequality, Poverty and Development. Journal of Development Economics, vol. 3 (4), p. $307-342$. Bigsten, A., Levin, J. (2001). Growth, Income Distribution, and Poverty: A Review. WIDER Discussion Paper (UNU), no. 2001/129, p. 25.

Blau, F., Kahn, L. (1996), International Differences in Male Wage Inequality: Institutions Versus Market Forces. Journal of Political Economy. № 104(4), pp. 791-837.

Bogdan, O., Tudorel, A. (2017). Income inequality in Romania: The exponential-Pareto distribution. Physica A: Statistical Mechanics and its Applications. Volume 469, pp. 486-498.

Castelló-Climent, A. (2010). Inequality and Growth in Advanced Economies: An Empirical Investigation. Journal of Economic Inequality. Springer, vol. 8(3), pages 293-321.

Chen, J., Si, Y., Li, F., Zhao, A. (2014). An Analysis of Relationship among Income Inequality, Poverty, and Income Mobility, Based on Distribution Functions. Hindawi Publishing Corporation. pp. 21-31.

Cristiano, P., Gaetano, M. (2008). Income Inequality Within European Regions: Determinants and Effects on Growth. Review of Income and Wealth Series, 54(3).

Emwanu, T., Kanyerezi Bwoogi, J., Muwonge, J. (1995). Data Collection Problems in Measuring Poverty Levels. Statistics Department, Ministry of Finance and Planning.

Ferreira, F., Gignoux, J. (2011). The Measurement of Inequality of Opportunity: Theory and an Application to Latin America. Review of Income and Wealth. Vol. 57(4), pp. 622-657.

Grootaert, C. (1994). Poverty and Basic Needs Fulfillment in Africa During Structural Change: Evidence from Cete d'Ivoire. World Development. Vol. 22(10), pp. 1521-34.

Guvenen, S., Kaplan, Song, J. (2014). How Risky Are Recessions for Top Earners? The American Economic Review. Papers \& Proceedings. Vol. 104(5), pp. 148-153.

Halvarsson, D., Korpib, M., Wennberg, K. (2017). Entrepreneurship and Income Inequality. CrossMark. Volume 145, pp. 275-293. 
Hertz, T., Jayasundera, T., Piraino, P., Selcuk, S., Smith, N., Verashchagina, A. (2007) The Inheritance of Educational Inequality: International Comparisons and Fifty-Year Trends. The B.E. Journal of Economic Analysis and Policy. Vol. 7(2)., pp. 1-46.

Jagielski, M., Duczmal R., Kutner, R. (2015). Income distribution in the European Union versus in the United States. Physic A: Statistical Mechanics and its Applications. Volume 433, pp. 36-41.

Martin, J. (2014). Activation and Active Labour Market Policies in OECD Countries: Stylized Facts and Evidence on their Effectiveness. IZA Policy paper. No.84.

Oancea, B., Tudorel, A., Pirjol, D. (2017). Income inequality in Romania: The exponential-Pareto distribution. Physica A: Statistical Mechanics and its Applications. 469. 486-498. Doi: 10.1016/j.physa.2016.11.094.

Perron, P. (1988). Trends and random walks in macroeconomic time series: Further evidence from a new approach. Journal of Economic Dynamics and Control. Vol. 12, pp. 297-332.

Townsend, P. (1993). The International Analysis of Poverty. New York: Harvester Wheatsceaf.

Wood, A. (1995). How Trade Hurts Unskilled Workers. Journal of Economic Perspectives. Vol. 9(3), pp. 57-80. 